\title{
In vivo rejection of tumor cells dependent on CD8 cells that kill independently of perforin and FasL
}

\author{
Sung-Hyung Lee, Erez Bar-Haim, Arthur Machlenkin, Ofir Goldberger, Ilan Volovitz, \\ Ezra Vadai, Esther Tzehoval, and Lea Eisenbach
}

Cancer Gene Therapy (2004); 11, 307. doi:10.1038/sj.cgt.7700715

Correction to: Cancer Gene Therapy (2004) doi: 10.1038/sj.cgt.7700678; Published Online: 23 January 2004

Due to a typesetting error, Figure 2 was published incomplete. The complete Figure 2 is printed below.

On page 244, 18 lines of text were printed in error. The sentence should read correctly as "The results in Figure $7 \mathrm{a}$ show that local tumors of $\mathrm{C} 57 \mathrm{BL} / 6$ and $\mathrm{B} 6-\mathrm{PKO}$ mice significantly progressed when the mice were depleted from the CD8 T-cell subpopulation." a

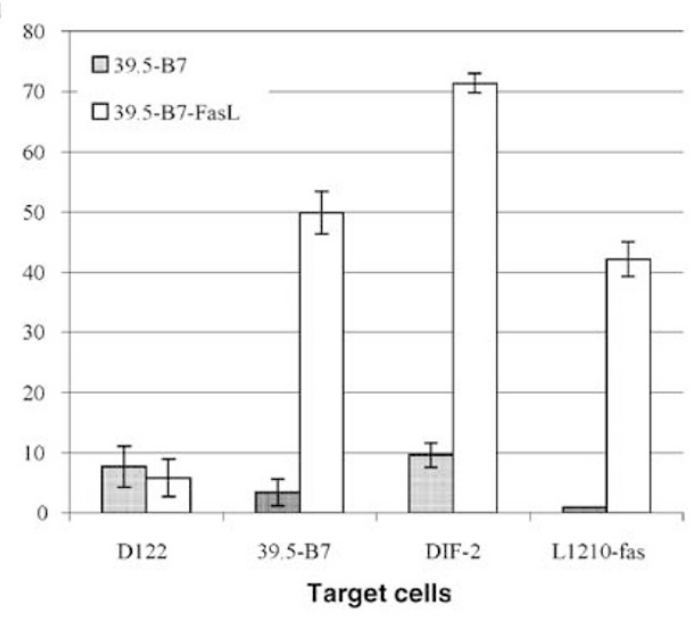

b

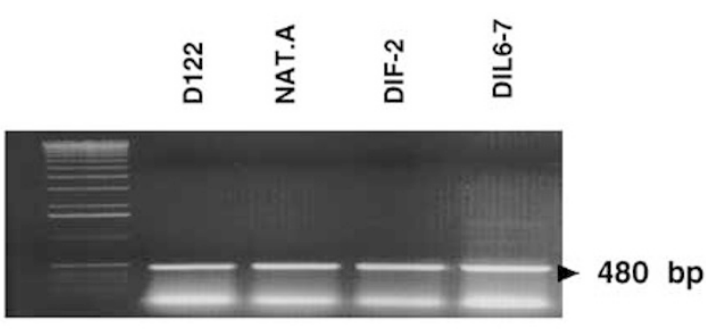

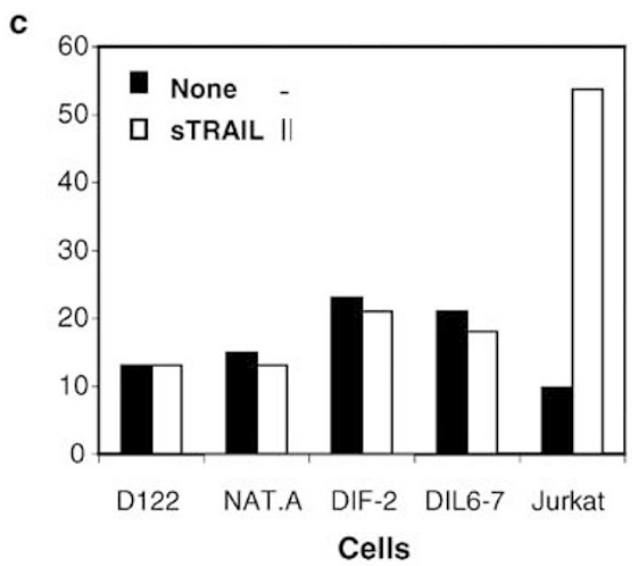

Figure 2 Sensitivity of the cells to FasL and TRAIL. (a) $\left[{ }^{35} \mathrm{~S}\right]$ methionine labeled target cells $\left(5 \times 10^{5}\right.$ cells/ml) were coincubated with FasLexpressing cells (39.5-B7-FasL) or with nonexpressor (39.5-B7) for $18 \mathrm{~h}$ and release of radioactivity was monitored. L1210-fas cells were used as a positive control. The data represent average \pm SD of triplicate in one of three independent experiments. (b) Expression of mTRAIL receptor (DR5) on parental D122 and cytokine transfectants (NAT.A, DIF-2 and DIL6-7) was tested according to Materials and methods. (c) Cells $\left(1 \times 10^{6}\right.$ cells) were incubated with STRAIL $(100 \mathrm{ng} / \mathrm{ml})$ overnight, and cells were analyzed by flow cytometry after staining with Annexin and PI. The data shows one of two independent experiments. 